\title{
The effect of mechanical-chemical cultivation on infestation of potato tubers by Rhizoctonia solani
}

\author{
Wpływ pielęgnacji mechaniczno-chemicznej \\ na porażenie bulw ziemniaka przez Rhizoctonia solani
}

\author{
Krystyna Zarzecka, Marek Gugała, Honorata Dołęga, Anna Sikorska
}

\section{Summary}

The studies were conducted at the Agricultural Experimental Farm of the University of Natural Sciences and Humanities in Siedlce, in 2008-2010. The experiment was set using a method of randomized sub-blocks as a two-factorial design. The first order factor were - potato cultivars: Cekin, Satina, Tajfun, second - order factors - methods of weed control involving herbicides and their mixtures: Command 480 EC, Command 480 EC and Afalon Dyspersyjny 450 SC, Stomp 400 SC, Stomp 400 SC and Afalon Dyspersyjny 450 SC and control object - mechanical weeding. The studies showed that the applied methods of weed control with herbicides significantly reduced the occurrence of black scurf on tubers, the average degree of tuber infestation and the average degree of infestation on infested tubers.

Key words: black scurf; potato; cultivars; herbicides

\section{Streszczenie}

Badania przeprowadzono w Rolniczej Stacji Doświadczalnej Uniwersytetu Przyrodniczo-Humanistycznego w Siedlcach, w latach 2008-2010. Doświadczenie założono metodą losowanych podbloków jako dwuczynnikowe. Czynnikiem I rzędu były odmiany ziemniaka - Cekin, Satina, Tajfun, czynnikiem II rzędu - sposoby odchwaszczania z udziałem herbicydów i ich mieszanin: Command 480 EC, Command 480 EC i Afalon Dyspersyjny 450 SC, Stomp 400 SC, Stomp 400 SC i Afalon Dyspersyjny 450 SC oraz obiekt kontrolny - pielęgnacja mechaniczna. Badania dowiodły, że zastosowane sposoby odchwaszczania z udziałem herbicydów w istotny sposób wpłynęły na ograniczenie występowania rizoktoniozy na bulwach, na średni stopień porażenia próby i średni stopień porażenia bulw porażonych.

Słowa kluczowe: rizoktonioza; ziemniak; odmiany; herbicydy

\author{
Uniwersytet Przyrodniczo-Humanistyczny w Siedlcach \\ Katedra Szczegółowej Uprawy Roślin \\ Prusa 14, 08-110 Siedlce \\ kzarzecka@uph.edu.pl
}




\section{Wstęp / Introduction}

Choroby i szkodniki występujące na plantacjach ziemniaka niszczą powierzchnię asymilacyjną roślin i w zależności od stopnia nasilenia mogą obniżyć plon nawet o 70\% (Beukema 1990; Nowacki 2006). W Polsce jedną z groźniejszych chorób ziemniaka jest rizoktonioza powodowana przez grzyb Rhizoctonia solani. Choroba ta występuje w różnych fazach rozwoju roślin w trzech formach: zgnilizna kiełków, próchnienie podstawy łodyg i ospowatość bulw. Gnicie kiełków powoduje opóźnienia w rozwoju i wypadanie roślin, natomiast ospowatość (czarne strupy na bulwach) jest chorobą skórki zaliczaną do wad zewnętrznych, która pogarsza estetykę bulw zmniejszając wartość handlową ziemniaka konsumpcyjnego i przeznaczonego do produkcji przetworów spożywczych, a porażone sadzeniaki stanowią źródło infekcji dla roślin potomnych (Gawińska-Urbanowicz 2007; Atkinson i wsp. 2010; Osowski i Bernat 2010). Skuteczną ochronę przed $R$. solani zapewnia zaprawianie sadzeniaków (Osowski i Bernat 2010; Atkinson i wsp. 2011).

Niektóre badania wskazuja, że intensyfikacja technologii uprawy ziemniaka zmniejsza straty plonu handlowego wskutek większej intensywności nawożenia i ochrony plantacji oraz stosowania poprawnej agrotechniki (Cwalina-Ambroziak i Wróbel 2005; Nowacki 2006; Klikocka 2008; Kraska i Pałys 2008; Zarzecka i wsp. 2009).
Prowadzone badania miały na celu określenie czy stosowane zabiegi mechaniczno-chemiczne regulujące zachwaszczenie wpływają również na porażenie bulw ziemniaka przez $R$. solani.

\section{Materiały i metody / Materials and methods}

Badania polowe przeprowadzono w Rolniczej Stacji Doświadczalnej Uniwersytetu Przyrodniczo-Humanistycznego w Siedlcach, w latach 2008-2010. Doświadczenie realizowano na glebie zaliczanej do kompleksu żytniego bardzo dobrego, klasy IVa, o odczynie lekko kwaśnym (rok 2010) i kwaśnym (lata 2008 i 2009). Założono je metodą losowanych podbloków, jako dwuczynnikowe, w trzech powtórzeniach. Czynnikiem I rzędu były średnio wczesne odmiany ziemniaka jadalnego - Cekin, Satina i Tajfun, a czynnikiem II rzędu - sposoby odchwaszczania: 1. pielęgnacja mechaniczna do i po wschodach rośliny uprawnej, 2. pielęgnacja mechaniczno-chemiczna $\mathrm{z}$ herbicydem Command $480 \mathrm{EC}$ w dawce 0,2 1/ha, 3. pielęgnacja mechaniczno-chemiczna $\mathrm{z}$ mieszaniną herbicydów Command 480 EC w dawce 0,2 1/ha i Afalon Dyspersyjny 1,0 1/ha, 4. pielęgnacja mechaniczno-chemiczna $\mathrm{z}$ herbicydem Stomp 400 SC stosowanym w dawce 3,5 1/ha, 5. pielęgnacja mechaniczno-chemiczna $\mathrm{z}$ mieszaniną herbicydów Stomp $400 \mathrm{SC}$ w dawce 3,5 1/ha i Afalon Dyspersyjny $1,0 \mathrm{l} / \mathrm{ha}$.

Tabela 1. Warunki meteorologiczne w okresie lipiec-wrzesień w latach 2008-2010

Table 1. Meteorological conditions from July to September in the years 2008-2010

\begin{tabular}{|c|c|c|c|c|c|c|}
\hline \multirow{2}{*}{$\begin{array}{l}\text { Miesiące } \\
\text { Months }\end{array}$} & \multirow{2}{*}{ Parametr - Parameter } & \multicolumn{3}{|c|}{ Dekady - Decades } & \multirow{2}{*}{$\begin{array}{l}\text { Średnia/Suma } \\
\text { Mean/Sum }\end{array}$} & \multirow{2}{*}{$\begin{array}{l}\text { Wielolecie } \\
\text { Multiyear }\end{array}$} \\
\hline & & I & II & III & & \\
\hline \multicolumn{7}{|c|}{2008} \\
\hline Lipiec & temperatura - temperature $\left[{ }^{\circ} \mathrm{C}\right]$ & 17,6 & 18,3 & 19,4 & 18,4 & 19,2 \\
\hline July & opady - rainfalls $[\mathrm{mm}]$ & 44,3 & 9,9 & 15,6 & 69.8 & 49,8 \\
\hline Sierpień & temperatura - temperature $\left[{ }^{\circ} \mathrm{C}\right]$ & 19,0 & 20,3 & 16,4 & 18,5 & 18,5 \\
\hline August & opady - rainfalls [mm] & 21,7 & 29,4 & 24,3 & 75,4 & 43,0 \\
\hline Wrzesień & temperatura - temperature $\left[{ }^{\circ} \mathrm{C}\right]$ & 18,2 & 8,7 & 9,8 & 12,2 & 13,1 \\
\hline September & opady - rainfalls [mm] & 21,9 & 25,5 & 16,0 & 63,4 & 47,3 \\
\hline \multicolumn{7}{|c|}{2009} \\
\hline Lipiec & temperatura - temperature $\left[{ }^{\circ} \mathrm{C}\right]$ & 19,2 & 19,7 & 19,4 & 19,4 & 19,2 \\
\hline July & opady - rainfalls [mm] & 14,9 & 3,9 & 7,6 & 26,4 & 49,8 \\
\hline Sierpień & temperatura - temperature $\left[{ }^{\circ} \mathrm{C}\right]$ & 18,9 & 17,2 & 16,9 & 17,7 & 18,5 \\
\hline August & opady - rainfalls [mm] & 9,3 & 28,6 & 43,0 & 80,9 & 43,0 \\
\hline Wrzesień & temperatura - temperature $\left[{ }^{\circ} \mathrm{C}\right]$ & 16,0 & 14,7 & 13,0 & 14,6 & 13,1 \\
\hline September & opady - tainfalls [mm] & 9,5 & 7,6 & 7,8 & 24,9 & 47,3 \\
\hline \multicolumn{7}{|c|}{2010} \\
\hline Lipiec & temperatura - temperature $\left[{ }^{\circ} \mathrm{C}\right]$ & 20,2 & 23,9 & 20,6 & 21,6 & 19,2 \\
\hline July & opady - rainfalls [mm] & 0,0 & 14,3 & 62,7 & 77,0 & 49,8 \\
\hline Sierpień & temperatura - temperature $\left[{ }^{\circ} \mathrm{C}\right]$ & 21,2 & 21,5 & 16,6 & 19,8 & 18,5 \\
\hline August & opady - rainfalls $[\mathrm{mm}]$ & 14,1 & 3,0 & 89,2 & 106,3 & 43,0 \\
\hline Wrzesień & temperatura - temperature $\left[{ }^{\circ} \mathrm{C}\right]$ & 11,5 & 12,4 & 11,5 & 11,8 & 13,1 \\
\hline September & opady - rainfalls [mm] & 85,2 & 11,1 & 13,6 & 109,9 & 47,3 \\
\hline
\end{tabular}


Przedplonem ziemniaka było pszenżyto ozime. Jesienią, przed założeniem doświadczenia, stosowano nawożenie naturalne obornikiem $\mathrm{w}$ dawce $25 \mathrm{t} / \mathrm{ha}$ oraz nawożenie mineralne fosforowo-potasowe w ilości $\mathrm{P}-44,0 \mathrm{~kg} / \mathrm{ha}$ (superfosfat potrójny 46\%) i K - 124,5 kg/ha (sól potasowa 60\%). Wiosną wysiewano nawozy azotowe w ilości $100 \mathrm{~kg} \mathrm{~N} / \mathrm{ha}$ (saletra amonowa 34\%). Bulwy ziemniaka sadzono w rozstawie rzędów $67,5 \mathrm{~cm}$, co $37 \mathrm{~cm}$ w rzędzie, w drugiej dekadzie kwietnia, a zbioru dokonywano w pierwszej dekadzie września.

Porażenie ziemniaków przez $R$. solani oceniano corocznie, bezpośrednio po zbiorze na 100 bulwach pobranych losowo z każdego obiektu doświadczenia (45 prób). Określono procentowy udział bulw porażonych, średni stopień porażenia bulw (wszystkich poddanych ocenie) i stopień porażenia bulw z objawami ospowatości w skali 1-9, gdzie 9 - oznacza bulwy zdrowe (brak objawów choroby), 5 - oznacza $5-10 \%$ powierzchni z objawami rizoktoniozy (liczne drobne i pojedyncze większe skleroty), a 1 - ponad $25 \%$ powierzchni $\mathrm{z}$ objawami rizoktoniozy (Roztropowicz i wsp. 1999). Wyniki badań opracowano statystycznie za pomocą analizy wariancji, a ocenę istotności różnic, przy poziomie $\mathrm{p}=0,05$ pomiędzy porównywalnymi średnimi testowano za pomocą wielokrotnych przedziałów Tukeya.

Sumy i rozkład opadów oraz temperatury powietrza w okresie lipca, sierpnia i września przedstawiono w tabeli 1 .

\section{Wyniki i dyskusja / Results and discussion}

W prowadzonych badaniach przeciętny procentowy udział bulw z objawami rizoktoniozy wynosił 7,4\%, średni stopień porażenia próby $-8,71$, a stopień porażenia bulw 6,58 w skali 9-stopniowej (tab. 2, 3, 4). Udział bulw porażonych zależał istotnie od sposobu odchwaszczania i odmiany. Zabiegi odchwaszczające z udziałem herbicydów i ich mieszanin zmniejszały występowanie ospowatości na bulwach wszystkich uprawianych odmian ziemniaka w porównaniu do obiektu kontrolnego (odchwaszczanie mechaniczne). Różnice pomiędzy obiektami, na których stosowano herbicydy nie były istotne. W doświadczeniach prowadzonych przez Boligłowę i wsp. (2004) stan zdrowotny bulw ziemniaka zależał od rodzaju użytego środka chwastobójczego. Także Kraska i Pałys (2008) odnotowali mniejsze porażenie bulw po zastosowaniu intensywnego nawożenia i ochrony w stosunku do poziomu podstawowego. Porażenie bulw na obiektach chronionych było mniejsze $\mathrm{w}$ porównaniu $\mathrm{z}$ odnotowanym na obiekcie kontrolnym (tab. 3, 4). Wcześniejsze badania Zarzeckiej i wsp. (2009) nie potwierdziły istotnego wpływu, ale wystapiła tendencja do poprawy tych cech po zastosowaniu chemicznej metody zwalczania chwastów.

Najmniejszy udział bulw $\mathrm{z}$ objawami rizoktoniozy wystapił u odmiany Satina - średnio 6,7\%, a istotnie większy $u$ odmiany Tajfun $-7,8 \%$. Najmniejszym stopniem porażenia bulw wynoszącym 6,68 charakteryzowała się odmiana Tajfun, a największym odmiana Cekin - 6,47 w 9-stopniowej skali. Świadczy to o zróżnicowanej reakcji odmian, a jednocześnie wskazuje, że przy doborze odmian do produkcji należy kierować się ich odpornością na choroby. Znaczne różnice odmianowe porażenia rizoktoniozą obserwowali również Wróbel (2006), Gawińska-Urbanowicz (2007), Krzysztofik (2008), Cwalina-Ambroziak i Bogucka (2012).

Podczas prowadzenia doświadczenia panowały zróżnicowane warunki pogodowe, a opady i temperatury powietrza w drugiej części okresu wegetacji w największym stopniu decydują o występowaniu ospowatości na bulwach ziemniaka. W badaniach istotny wpływ na procentowy udział bulw $\mathrm{z}$ objawami rizoktoniozy, średni stopień porażenia próby i stopień porażenia bulw miały warunki atmosferyczne w okresach wegetacji (tab. 5). Największy

Tabela 2. Procentowy udział bulw z objawami rizoktoniozy w zależności od odmiany i sposobów odchwaszczania Table 2. Percentage share of tubers with black scurf symptoms depending on the cultivars and weed control methods

\begin{tabular}{|c|c|c|c|c|}
\hline \multirow{3}{*}{$\begin{array}{l}\text { Sposoby odchwaszczania } \\
\text { Weed control methods }\end{array}$} & \multicolumn{4}{|c|}{$\begin{array}{l}\text { Udział bulw porażonych } \\
\text { Share of infested tubers }\end{array}$} \\
\hline & \multicolumn{3}{|c|}{ odmiany - cultivars } & \multirow{2}{*}{$\begin{array}{c}\text { średnio } \\
\text { mean }\end{array}$} \\
\hline & Cekin & Satina & Tajfun & \\
\hline $\begin{array}{l}\text { Obiekt kontrolny - pielęgnacja mechaniczna } \\
\text { Control object - mechanical weeding }\end{array}$ & 10,6 & 10,1 & 11,1 & 10,6 \\
\hline Command $480 \mathrm{EC}$ & 7,1 & 6,0 & 7,6 & 6,9 \\
\hline Command $480 \mathrm{EC}+$ Afalon Dyspersyjny $450 \mathrm{SC}$ & 5,5 & 4,9 & 6,0 & 5,5 \\
\hline Stomp $400 \mathrm{SC}$ & 8,0 & 6,8 & 8,2 & 7,7 \\
\hline Stomp $400 \mathrm{SC}+$ Afalon Dyspersyjny $450 \mathrm{SC}$ & 6,1 & 5,9 & 6,2 & 6,1 \\
\hline Średnio - Mean & 7,5 & 6,7 & 7,8 & 7,4 \\
\hline $\begin{array}{l}\text { NIR }(0,05) \text { - LSD }(0.05) \\
\text { Odmiany - Cultivars } \\
\text { Sposoby odchwaszczania - Weed control methods } \\
\text { Interakcja - Interaction }\end{array}$ & & & & $\begin{array}{l}1,0 \\
2,5 \\
\text { r.n. }\end{array}$ \\
\hline
\end{tabular}

r.n. - różnice nieistotne - not significant differences 
Tabela 3. Średni stopień porażenia próby bulw przez $R$. solani w zależności od sposobów odchwaszczania i lat badań

Table 3. Mean degree of tuber infested by black scurf depending on the weed control methods and years

\begin{tabular}{|c|c|c|c|c|}
\hline \multirow{3}{*}{$\begin{array}{l}\text { Sposoby odchwaszczania } \\
\text { Weed control methods }\end{array}$} & \multicolumn{4}{|c|}{$\begin{array}{l}\text { Średni stopień porażenia bulw (skala 1-9) } \\
\text { Mean degree of tuber infestation (scale 1-9) }\end{array}$} \\
\hline & \multicolumn{3}{|c|}{ lata - years } & \multirow{2}{*}{$\begin{array}{c}\text { średnio } \\
\text { mean }\end{array}$} \\
\hline & 2008 & 2009 & 2010 & \\
\hline $\begin{array}{l}\text { Obiekt kontrolny - pielęgnacja mechaniczna } \\
\text { Control object - mechanical weeding }\end{array}$ & 8,32 & 8,19 & 8,98 & 8,49 \\
\hline Command $480 \mathrm{EC}$ & 8,58 & 8,66 & 9,00 & 8,75 \\
\hline Command 480 EC + Afalon Dyspersyjny $450 \mathrm{SC}$ & 8,71 & 8,71 & 9,00 & 8,81 \\
\hline Stomp $400 \mathrm{SC}$ & 8,49 & 8,64 & 9,00 & 8,71 \\
\hline Stomp 400 SC + Afalon Dyspersyjny 450 SC & 8,68 & 8,75 & 9,00 & 8,81 \\
\hline Średnio - Mean & 8,56 & 8,59 & 8,99 & 8,71 \\
\hline $\begin{array}{l}\text { NIR }(0,05) \text { - LSD }(0.05) \\
\text { Sposoby odchwaszczania - Weed control methods } \\
\text { Lata - Years } \\
\text { Interakcja - Interaction }\end{array}$ & & & & $\begin{array}{l}0,16 \\
0,09 \\
0,28\end{array}$ \\
\hline
\end{tabular}

Tabela 4. Średni stopień porażenia bulw porażonych przez $R$. solani w zależności od odmian i sposobów odchwaszczania

Table 4. Mean degree of infested by black scurf tuber infestation depending on the cultivars and weed control methods

\begin{tabular}{|c|c|c|c|c|}
\hline \multirow{3}{*}{$\begin{array}{l}\text { Sposoby odchwaszczania } \\
\text { Weed control methods }\end{array}$} & \multicolumn{4}{|c|}{$\begin{array}{l}\text { Średni stopień porażenia bulw porażonych } \\
\text { przez } R \text {. solani (skala } 1-9 \text { ) } \\
\text { Mean degree of infested by } R \text {. solani } \\
\text { tuber infestation (scale } 1-9 \text { ) }\end{array}$} \\
\hline & \multicolumn{3}{|c|}{ odmiany - cultivars } & \multirow{2}{*}{$\begin{array}{l}\text { średnio } \\
\text { mean }\end{array}$} \\
\hline & Cekin & Satina & Tajfun & \\
\hline $\begin{array}{l}\text { Obiekt kontrolny - pielęgnacja mechaniczna } \\
\text { Control object - mechanical weeding }\end{array}$ & 6,09 & 5,58 & 6,12 & 5,93 \\
\hline Command $480 \mathrm{EC}$ & 6,58 & 6,66 & 6,80 & 6,68 \\
\hline Command $480 \mathrm{EC}+$ Afalon Dyspersyjny $450 \mathrm{SC}$ & 6,65 & 7,03 & 6,90 & 6,86 \\
\hline Stomp $400 \mathrm{SC}$ & 6,29 & 6,64 & 6,58 & 6,50 \\
\hline Stomp 400 SC + Afalon Dyspersyjny 450 SC & 6,74 & 6,98 & 6,99 & 6,90 \\
\hline Średnio - Mean & 6,47 & 6,58 & 6,68 & 6,58 \\
\hline $\begin{array}{l}\text { NIR }(0,05) \text { - LSD }(0.05) \\
\text { Odmiany - Cultivars } \\
\text { Sposoby odchwaszczania - Weed control methods } \\
\text { Interakcja - Interaction }\end{array}$ & & & & $\begin{array}{l}0,59 \\
0,48 \\
\text { r.n. }\end{array}$ \\
\hline
\end{tabular}

r.n. - różnice nieistotne - not significant differences

Tabela 5. Porażenie bulw ziemniaka przez R. solani w latach badań (w \% i skali 1-9)

Table 5. Infestation of potato tubers by black scurf in the study years (in \% and scale 1-9)

\begin{tabular}{l|c|c|c|c|c}
\hline \multicolumn{1}{c|}{$\begin{array}{c}\text { Wyszczególnienie } \\
\text { Specification }\end{array}$} & \multicolumn{2}{c|}{ Lata - Years } & \multirow{2}{*}{$\begin{array}{c}\text { Średnio } \\
\text { Mean }\end{array}$} & $\begin{array}{c}\text { NIR (0,05) } \\
\text { LSD (0.05) }\end{array}$ \\
\cline { 2 - 5 } $\begin{array}{l}\text { Procent bulw porażonych } \\
\text { Percentage of infested tubers }\end{array}$ & 12,2 & 9,5 & 0,4 & 7,4 & 1,6 \\
\hline $\begin{array}{l}\text { Średni stopień porażenia próby (skala 1-9) } \\
\text { Mean degree of sample infestation (scale 1-9) }\end{array}$ & 8,56 & 8,59 & 8,99 & 8,71 & 0,09 \\
\hline $\begin{array}{l}\text { Średni stopień porażenia bulw przez R. solani (skala 1-9) } \\
\text { Mean degree of tuber infestation by R. solani (scale 1-9) }\end{array}$ & 5,57 & 5,29 & 8,87 & 6,58 & 0,59 \\
\hline
\end{tabular}

udział bulw chorych i największe ich porażenie odnotowano w 2008 roku, w którym lipiec i sierpień były chłodne, temperatura wahała się od 17,6 do $20,3^{\circ} \mathrm{C}$. Natomiast najmniej bulw porażonych i charakteryzujących się najmniejszym porażeniem stwierdzono w 2010 roku, kiedy miesiące lipiec i sierpień były najcieplejsze. W okresie tym 
także opady były niewielkie. Warunki atmosferyczne września nie miały większego znaczenia, gdyż zbiór ziemniaka przeprowadzano $\mathrm{w}$ pierwszej dekadzie września. Podobny wpływ warunków pogodowych na występowanie rizoktoniozy odnotowali Wróbel (2006) oraz Gawińska-Urbanowicz (2007). Lutomirska (2007) wykazała, że optymalne warunki dla rozwoju grzyba $R$. solani dla odmian późniejszych stwarza temperatura $12,1-18,2^{\circ} \mathrm{C}$ oraz wysoka wilgotność. W prowadzonym doświadczeniu stwierdzono interakcję sposobów odchwaszczania z latami badań w kształtowaniu stopnia porażenia bulw przez R. solani. W badaniach Kraski i Pałysa (2008) zastosowanie intensywnego poziomu chemizacji także istotnie ograniczyło stopień porażenia bulw przez $R$. solani, szczególnie w roku, w którym średnia temperatura powietrza była najwyższa.

\section{Wnioski / Conclusions}

1. Zabiegi mechaniczno-chemiczne regulujące zachwaszczenie wykazały korzystny, istotny wpływ na procentowy udział bulw z objawami rizoktoniozy, stopień porażenia bulw i stopień porażenia bulw porażonych w porównaniu do bulw zebranych z obiektu kontrolnego odchwaszczanego mechanicznie.

2. Odmiany uprawiane $\mathrm{w}$ doświadczeniu różniły się istotnie udziałem bulw porażonych i stopniem porażenia bulw rizoktoniozą.

3. Warunki meteorologiczne w latach badań decydowały o liczbie bulw z objawami rizoktoniozy i stopniu ich porażenia.

\section{Literatura / References}

Atkinson D., Thornton M.K., Miller J.S. 2010. Development of Rhizoctonia solani on stems, stolons and tubers of potatoes. I. Effect of inoculum source. Am. J. Potato Res. 87: 374-381.

Atkinson D., Thornton M.K., Miller J.S. 2011. Development of Rhizoctonia solani on stems, stolons and tubers of potatoes. II. Efficacy of chemical applications. Am. J. Potato Res. 88: 96-103.

Beukema H.P., Van der Zaag D.E. 1990. Introduction to Potato Production. Pudoc, Wageningen, 208 pp.

Boligłowa E., Gleń K., Pisulewski P. 2004. Wpływ stosowania herbicydów na plonowanie i niektóre cechy jakości bulw ziemniaka. Zesz. Probl. Post. Nauk Rol. 500: 391-397.

Cwalina-Ambroziak B., Wróbel E. 2005. Wpływ nawożenia azotem na występowanie ważniejszych chorób na bulwach ziemniaka. Biul. IHAR 237/238: 169-176.

Cwalina-Ambroziak B., Bogucka B. 2012. Pathogens of potato (Solanum tuberosum L.) tuber (Phytophtora infestans) occurring in treatments with foliar fertilization. Acta Agrobot. 65 (3): 75-84.

Gawińska-Urbanowicz H. 2007. Ocena występowania chorób grzybowych i bakteryjnych ziemniaka w warunkach polowych. Biul. IHAR 243: 191-197.

Klikocka H. 2009. Influence of NPK fertilization enriched with S, Mg, and micronutrients contained in liquid fertilizer Insol 7 on potato tubers yield (Solanum tuberosum L.) and infestation of tubers Streptomyces scabies and Rhizoctonia solani. J. Elementol. 14 (2): 271-288.

Kraska P., Pałys E. 2008. Wpływ systemów uprawy roli oraz poziomów nawożenia i ochrony na porażenie bulw ziemniaka przez Streptomyces scabies i Rhizoctonia solani. [The influence of tillage systems and fertilization and plant protection levels on potato tuber infestation by Streptomyces scabies and Rhizoctonia solani]. Prog. Plant Prot./Post. Ochr. Roślin 48 (1): $204-207$.

Krzysztofik B. 2008. Wpływ miejsca przechowywania na zmiany cech jakościowych bulw ziemniaka. Acta Agrophys. 11 (2): $449-456$.

Lutomirska B. 2007. Wpływ odmiany i czynników meteorologicznych okresu wegetacji na ospowatość bulw ziemniaka. [The influence of meteorological factors on tuber infection with common scab]. Prog. Plant Prot./Post. Ochr. Roślin 47 (2): 173-177.

Nowacki W. 2006. Straty plonu handlowego ziemniaków powodowane przez choroby i szkodniki w 2005 roku. [Losses in potato market yield caused by diseases and pests]. Prog. Plant Prot./Post. Ochr. Roślin 46 (1): 193-201.

Osowski J., Bernat E. 2010. Wpływ terminów zaprawiania i krojenia bulw na tempo wschodów i porażenie roślin rizoktoniozą ziemniaka. [The effect of date of seed dressing and cutting of tuber on emergence rate and infection of plant by Rhizoctonia canker]. Prog. Plant Prot./Post. Ochr. Roślin 50 (2): 687-694.

Wróbel S. 2006. Wpływ podkiełkowywania sadzeniaków na plon oraz porażenie bulw ospowatością i parchem zwykłym. Acta Sci. Pol., Agricultura 5 (1): 93-101.

Zarzecka K., Gugała M., Rymuza K. 2009. Wpływ metod agrotechnicznych i herbicydów na porażenie przez rizoktoniozę (Rhizoctonia solani) bulw ziemniaka odmiany Wiking. Biul. IHAR 251: 235-241. 